\title{
Validation of Medical Tourism Service Quality Questionnaire (MTSQQ) for Iranian Hospitals
}

\author{
Mohammad Qolipour $^{1}$, Amin Torabipour ${ }^{2}$, Farzad Faraji Khiavi², Amal Saki Malehi ${ }^{3}$
}

\begin{abstract}
${ }^{1}$ M.Sc. Student of Health Services Management, Department of Health Services Management, Faculty of Health, Ahvaz Jundishapur University of Medical Sciences , Ahvaz, Iran

${ }^{2}$ Ph.D. of Health Services Management, Assistant Professor, Department of Health Services Management, Faculty of Health, Ahvaz Jundishapur University of Medical Sciences , Ahvaz, Iran

${ }^{3}$ Ph.D. of Biostatistics, Assistant Professor, Department of Epidemiology and Biostatistics, Faculty of Health, Ahvaz Jundishapur University of Medical Sciences , Ahvaz, Iran
\end{abstract}

\section{Type of article: Original}

\begin{abstract}
Introduction: Assessing service quality is one of the basic requirements to develop the medical tourism industry. There is no valid and reliable tool to measure service quality of medical tourism. This study aimed to determine the reliability and validity of a Persian version of medical tourism service quality questionnaire for Iranian hospitals.

Methods: To validate the medical tourism service quality questionnaire (MTSQQ), a cross-sectional study was conducted on 250 Iraqi patients referred to hospitals in Ahvaz (Iran) from 2015. To design a questionnaire and determine its content validity, the Delphi Technique ( 3 rounds) with the participation of 20 medical tourism experts was used. Construct validity of the questionnaire was assessed through exploratory and confirmatory factor analysis. Reliability was assessed using Cronbach's alpha coefficient. Data were analyzed by Excel 2007, SPSS version 18 , and Lisrel 18.0 software.

Results: The content validity of the questionnaire with $\mathrm{CVI}=0.775$ was confirmed. According to exploratory factor analysis, the MTSQQ included 31 items and 8 dimensions (tangibility, reliability, responsiveness, assurance, empathy, exchange and travel facilities, technical and infrastructure facilities and safety and security). Construct validity of the questionnaire was confirmed, based on the goodness of fit quantities of model (RMSEA $=0.032, \mathrm{CFI}=0.98, \mathrm{GFI}=0.88$ ). Cronbach's alpha coefficient was 0.837 and 0.919 for expectation and perception questionnaire.

Conclusion: The results of the study showed that the medical tourism SERVQUAL questionnaire with 31 items and 8 dimensions was a valid and reliable tool to measure service quality of medical tourism in Iranian hospitals.

Keywords: Hospital, Medical tourism, SERVQUAL, Validity, Reliability
\end{abstract}

\section{Introduction}

Medical tourism, as a part of health tourism, is a developing industry (1). Medical tourism is defined as "the travel of people to a place other than where they normally reside, for the purpose of obtaining medical treatment in that country" (2). The issue of medical tourism in Iran has been considered in recent years. The special geographical situation, the history of medical sciences, highly qualified medical and paramedical staff and low-cost health services can increase the importance of medical tourism in Iran (3). According to Iran's 2025 vision document, it is predicted Iran will have annually more than 40 million domestic tourists and 20 million foreign tourists (4). Assessing hospital service quality is one of the basic requirements to develop medical tourism industry (5). Today, the quality of medical services is the most important issue in health systems. Improving quality of health services is a key strategy to achieve additional support, competitive and long-term profitability advantages and health outcomes

\section{Corresponding author:}

Assistant Professor Dr. Amin Torabipour, Department of Health Services Management, Faculty of Health, Ahvaz Jundishapur University of Medical Sciences, Ahvaz, Iran.

Tel: +98.6133738269, Fax: +98.6133738282, Email: torabi-a@ajums.ac.ir

Received: September 19, 2016, Accepted: January 12, 2017, Published: March 2017

iThenticate screening: November 25, 2016, English editing: February 09, 2017, Quality control: March 02, 2017

(C) 2017 The Authors. This is an open access article under the terms of the Creative Commons Attribution-NonCommercialNoDerivs License, which permits use and distribution in any medium, provided the original work is properly cited, the use is non-commercial and no modifications or adaptations are made. 
for patients in health organizations (6). Quality of health services has two dimensions: technical quality (outcome quality) and performance quality (service quality). Technical quality refers to the accuracy of treatment process, and performance quality relates to the method of service delivery. From a patient's viewpoint, service quality is more important than technical quality (due to lack of technical knowledge) (7). Traditionally, health indicators such as mortality rate and prevalence of disease were used as an indicator of clinical quality assessment $(8,9)$. In the past, service quality was assessed using a one-dimension scale, although, a one-dimension scale was not appropriate to measure services quality as a multi-dimension concept (10). One of the most applied and useful tools to measure service quality is SERVQUAL. This tool measures customers' perceptions and expectations of services in five dimensions: "tangibles" measure the physical facilities, equipment, and appearance of personnel; "reliability" is defined as the ability of the service provider to perform the promised service dependably and accurately; "responsiveness" measures the willingness of the service personnel to help customers and provide prompt service; "assurance" is defined as the knowledge and courtesy of employees and their ability to inspire trust and confidence among consumers; and "empathy" is defined as caring, individualized attention that the firm provides for its customers (11-13). No study had been conducted to assess the services quality of medical tourism in Ahvaz. In the field of health services, most services quality assessment studies have been conducted in the field of hospital services. Lim and Tang (14), Tucker and Adams (15), Jabnoun and Chaker (16), Sohail (17) and Boshoff and Gray (18) assessed the hospital service quality using SERVQUAL model. There is no valid and relevant questionnaire for assessing medical tourism service quality. Therefore, this study aimed to determine the reliability and validity of a Persian version of a medical tourism service quality questionnaire.

\section{Material and Methods}

\subsection{Research design}

This cross-sectional study was conducted in 2015. In this study, quality of medical tourism services was studied in view of 250 patients referred to private and public hospitals in Ahvaz.

\subsection{Development of questionnaire}

The development of Iranian medical tourism service quality questionnaire (MTSQQ) was begun by reviewing the related literature and available SERVQUAL model that was developed by Parasuraman and Zeithaml (13). Also, we used the hospital service quality models including Joint Committee on Accreditation in Health Organizations (JCAHO), clinical governance model, 5Q model and Medical Tourism Agenda of Iran's Ministry of Health to develop the instrument.

\subsection{Content validity}

Thirty three key informants were selected using snowball sampling methods. The inclusion criteria to select key informants were as follows: 1) at least three years of work experience in medical tourism, and 2) having at least one article published related to service quality and medical tourism. Finally, twenty questionnaires were completed (response rate of $60 \%$ ). To design a valid questionnaire and determine its content validity, the Delphi technique (3 rounds) with the participation of 20 medical tourism experts was used. Finally, Lawshe's method was used to determine content validity index (CVI) and content validity rate (CVR) of the questionnaire (19). Accepting or rejecting a question was made according to the following criteria: 1) Accepting a question if the validity of its CVR was equal to 0.42 or more; 2) Submitting a question in the next round of Delphi; If the validity of its CVR was between zero and $0.42 ; 3$ ). Rejecting a question; If the validity of its CVR was below zero. After items had been identified for inclusion in the final form, the content validity index (CVI) was calculated. After performing three rounds of Delphi technique, 32 items were approved for a final medical tourism quality service questionnaire.

\subsection{Construct validity}

To determine the construct validity, questionnaires were completed by 250 Iraqi patients who referred to Ahvaz hospitals randomly. In the final phase, to determine the hidden dimensions of the questionnaire, exploratory factor analysis (EFA) was performed through a varimax rotation method. Also, confirmatory factor analysis (CFA) was used to determine the relationship between causal variables. The reliability of the questionnaire was determined using Cronbach alpha. Data were analyzed by Excel 2007, Spss.18, and Lisrel8.0 software.

\section{Results}

In this study, $95 \%$ (19 persons) of key informants were male. Mean age of samples was $35.5( \pm 8.97)$. Most experts (75\%) had between 5-10 years' job experience and $80 \%$ of them had a Ph.D. degree. Also, $40 \%$ of them worked at 
universities and research centers, $20 \%$ of the key informants held jobs at hospitals and medical centers, and $40 \%$ at Ministry of Health. In the first round of the Delphi technique, 25 items with CVR more than 0.42 were verified.

Table 1. The content validity rate of the first round items

\begin{tabular}{|l|l|l|l|}
\hline The items were submitted to the second round & CVR & The suggestions were submitted to the second round & $\%$ \\
\hline Modern and up-to-date equipment & 0.40 & There are places to stay near the hospital & 50 \\
\hline Protecting patient records correctly by staff & 0.40 & $\begin{array}{l}\text { There is an office with administrative and } \\
\text { commercial facilities for patients and their relatives }\end{array}$ & 50 \\
\hline $\begin{array}{l}\text { Hospital adequately supports staff to provide } \\
\text { better service }\end{array}$ & 0.30 & $\begin{array}{l}\text { There is the possibility to transfer a patient from the } \\
\text { airport to the hospital }\end{array}$ & 50 \\
\hline Staff want the best benefits for patients & 0 & $\begin{array}{l}\text { Patients' transparent complaint process and } \\
\text { responsiveness at the right time }\end{array}$ & 60 \\
\hline $\begin{array}{l}\text { Hospital staffs' appropriate working hours for } \\
\text { patients }\end{array}$ & 0.40 & $\begin{array}{l}\text { Confidentiality of information is ensured to the } \\
\text { patient }\end{array}$ & 50 \\
\hline $\begin{array}{l}\text { Adequate transportation facilities by the } \\
\text { hospital }\end{array}$ & 0.40 & Accreditation of hospital is globally accepted & 50 \\
\hline $\begin{array}{l}\text { Coordination between hospital and standard } \\
\text { hotels to stay patient }\end{array}$ & 0.40 & Respect to the patients' rights & 50 \\
\hline $\begin{array}{l}\text { Hospital staff have adequate skills to use } \\
\text { information technology for patient care }\end{array}$ & 0.40 & - & \\
\hline $\begin{array}{l}\text { There is a unit in the hospital to protect the } \\
\text { patient's property }\end{array}$ & 0.30 & - & \\
\hline
\end{tabular}

Table 2. The content validity rate of the second round items

\begin{tabular}{|l|l|l|l|l|l|l|}
\hline no. & The items were submitted to the second round & Essential & Useful & $\begin{array}{l}\text { Not } \\
\text { necessary }\end{array}$ & CVR & Result \\
\hline 1 & Modern and up-to-date equipment & 7 & 7 & 6 & -0.3 & Reject \\
\hline 2 & Protecting patient records correctly by staff & 15 & 5 & 0 & 0.5 & Accept \\
\hline 3 & $\begin{array}{l}\text { Hospital adequately supports staff to provide better } \\
\text { service }\end{array}$ & 8 & 5 & 7 & -0.2 & Reject \\
\hline 4 & Staff want the best benefits for patients & 8 & 2 & 10 & -0.2 & Reject \\
\hline 5 & Hospital staffs' appropriate working hours for patients & 16 & 4 & 0 & 0.6 & Accept \\
\hline 6 & Adequate transportation facilities by the hospital & 6 & 5 & 9 & -0.4 & Reject \\
\hline 7 & $\begin{array}{l}\text { Coordination between hospital and standard hotels to } \\
\text { stay patient }\end{array}$ & 6 & 5 & 9 & -0.4 & Reject \\
\hline 8 & $\begin{array}{l}\text { Hospital staff have adequate skills to use information } \\
\text { technology for patient care }\end{array}$ & 7 & 4 & 9 & -0.3 & Reject \\
\hline 9 & $\begin{array}{l}\text { There is a unit in the hospital to protect the patient's } \\
\text { property }\end{array}$ & 7 & 5 & 8 & -0.3 & Reject \\
\hline no. & \begin{tabular}{l} 
The suggestions were submitted to the second round \\
\hline 1
\end{tabular} & Essential & Useful & $\begin{array}{l}\text { Not } \\
\text { necessary }\end{array}$ & CVR & Result \\
\hline 2 & $\begin{array}{l}\text { There is an office with administrative and commercial } \\
\text { facilities for patients and their relatives }\end{array}$ & 15 & 4 & 1 & 0.6 & Accept \\
\hline 3 & $\begin{array}{l}\text { There is the possibility to transfer a patient from the } \\
\text { airport to the hospital }\end{array}$ & 6 & 5 & 9 & Accept \\
\hline 4 & $\begin{array}{l}\text { Patients' transparent complaint process and } \\
\text { responsiveness at the right time }\end{array}$ & 16 & 4 & 0 & - & Reject \\
\hline 5 & Confidentiality of information is ensured to the patient & 15 & 3 & 2 & 0.04 & Accept \\
\hline 6 & Accreditation of hospital is globally accepted & 16 & 4 & 0 & 0.5 & Accept \\
\hline 7 & Respect to the patients' rights & 8 & 3 & 1 & -0.2 & Accept \\
\hline
\end{tabular}

Nine remaining items with the CVR between 0 and 0.42 were submitted to the second round of the Delphi technique. Also, seven items were suggested by $42 \%$ of experts, and were submitted to the second round of the Delphi technique (Table 1). In the second round, seven items with CVR higher than 0.42 were accepted and the 9 
remaining items were rejected by CVR less than zero (Table 2). In the second round, CVR of nine items was between 0.42 and 0 , these items were not submitted in the third round. Therefore, according to the results of the first and second round, in the third round, 31 items in two expectation and perception domains were developed to design the questionnaire (Table 3). To determine the construct validity, expectation and perception questionnaires were completed by 250 Iraqi patients, before admission and after discharge. Results of exploratory factor analysis for both expectation and perception questionnaires identify eight dimensions. The eight factors of expectation and perception questionnaires explained 72.97 and 81.98 of the variance, respectively. To determine the correlation between variables, the rotated component matrix was used. Items with a correlation more than 0.6 set into one dimension. The results of validation of the questionnaire in two, served different conditions (before admission and after discharge), the number of expectation questionnaire dimensions and items were equal to the perception questionnaire. The goodness of fit indexes used in the proposed model were the $\chi^{2} / \mathrm{df}$ Index, GFI (Goodness of Fit Index), CFI (Comparative Fitness Index), NFI (Normed Fit Index), RMSEA (Root Mean Square Error of Approximation). The results showed that these indexes were acceptable to descript the model. Finally, to denominate dimensions of MTSQQ, the experts' comments were used (Table 4). Cronbach's alpha coefficient was 0.837 and 0.919 for expectation and perception questionnaire; therefore, these instruments were reliable.

Table 3. The final approved items after two rounds of Delphi technique

\begin{tabular}{|c|c|c|c|}
\hline no. & Item & no. & Item \\
\hline 1 & Modern and up-to-date equipment & 17 & Understanding the specific needs of patients \\
\hline 2 & $\begin{array}{l}\text { Visually appealing physical } \\
\text { facilities }\end{array}$ & 18 & Hospital staffs' appropriate working hours for patients \\
\hline 3 & Neat and well-dressed personnel & 19 & Foreign exchange facilities are provided within the premises \\
\hline 4 & $\begin{array}{l}\text { Providing hospital services to } \\
\text { patients with interest }\end{array}$ & 20 & Payment facilities are easy and flexible \\
\hline 5 & $\begin{array}{l}\text { Accreditation of the hospital is } \\
\text { globally accepted }\end{array}$ & 21 & Adequate transportation facilities by the medical care unit \\
\hline 6 & $\begin{array}{l}\text { Provide services at the time } \\
\text { promised }\end{array}$ & 22 & There are appropriate places near the hospital to stay \\
\hline 7 & $\begin{array}{l}\text { Protecting patient records correctly } \\
\text { by staff }\end{array}$ & 23 & 24 hours internet connectivity inside the premises \\
\hline 8 & $\begin{array}{l}\text { Providing a detailed description of } \\
\text { the provided services to patients by } \\
\text { staff }\end{array}$ & 24 & The website provides adequate information on illness treatment \\
\hline 9 & $\begin{array}{l}\text { Providing prompt service to patients } \\
\text { by staff }\end{array}$ & 25 & Guaranteed reservation by the medical care unit \\
\hline 10 & $\begin{array}{l}\text { Staffs' continual willingness to help } \\
\text { patients }\end{array}$ & 26 & $\begin{array}{l}\text { There is an office with administrative and commercial facilities } \\
\text { for patients and their relatives }\end{array}$ \\
\hline 11 & $\begin{array}{l}\text { Patients' transparent complaint } \\
\text { process and responsiveness at the } \\
\text { right time }\end{array}$ & 27 & $\begin{array}{l}\text { There are translation services in hospitals to facilitate personal } \\
\text { relations and translate patients' medical records }\end{array}$ \\
\hline 12 & Polite providers & 28 & The doctors and nurses speak English / Arabic well \\
\hline 13 & $\begin{array}{l}\text { The patient's feeling of security in } \\
\text { treating with providers }\end{array}$ & 29 & Providing safe medication services in a hospital \\
\hline 14 & $\begin{array}{l}\text { Providers have sufficient knowledge } \\
\text { to answer the patient }\end{array}$ & 30 & $\begin{array}{l}\text { Observe patient safety principles in the provision of technical } \\
\text { services in a hospital (injections, dressings, nursing services and } \\
\text { medical examinations, etc.) }\end{array}$ \\
\hline 15 & $\begin{array}{l}\text { Confidentiality of information is } \\
\text { ensured to the patient }\end{array}$ & 31 & $\begin{array}{l}\text { There is enough safety in the prevention of hospital events } \\
\text { including falling out of bed, stumbling, etc. }\end{array}$ \\
\hline 16 & Individual attention to patients & & \\
\hline
\end{tabular}


Table 4. Denomination of verified dimensions of medical tourism service quality questionnaire (MTSQQ)

\begin{tabular}{|l|l|l|}
\hline no. & Name of dimension & Number of items \\
\hline 1 & Tangibility & $1,2,3$ \\
\hline 2 & Reliability & $4,5,6,7$ \\
\hline 3 & Responsiveness & $8,9,10,11$ \\
\hline 4 & Assurance & $12,13,14,15$ \\
\hline 5 & Empathy & $16,17,18$ \\
\hline 6 & Exchange and travel facilities & $19,20,21,22$ \\
\hline 7 & Technical and infrastructure facilities & $23,24,25,26,27,28$ \\
\hline 8 & Safety and security & $29,30,31$ \\
\hline
\end{tabular}

\section{Discussion}

The aim of this study was to validate a questionnaire to assess service quality of medical tourism in Iranian hospitals. SERVQUAL questionnaire is used to analyze the quality gap (Expectation-Perception) in different industries in view of customers (20). In this study, using the Delphi technique (3 rounds) and the medical tourism expert's comments, the final questionnaire was designed. Content validity index of questionnaire $(\mathrm{CVI}=0.775)$ was good. High quantity of CVI shows the necessity and importance of items to design a questionnaire $(21,22)$. In a similar study that was conducted by Prakash and Pallepati, this quantity was calculated as 0.96 (23). This quantity showed the high content validity of the SERVQUAL questionnaire. Also, in other studies to validate hospital service quality questionnaire, Soita (24) and Mahalakshmi et al. (25) calculated high CVI quantity. Results of exploratory factor analysis for both expectation and perception questionnaires, showed eight dimensions. The eight factors of expectation and perception questionnaires explained 72.97 and 81.98 of the variance, respectively. This means that expectations and perceptions designed questionnaires to measure the service quality of medical tourism, were valid (26). In the present study, the results of exploratory factor analysis showed that both questionnaires in two different conditions of service delivery, including patients' perception (before admission) and patients' expectation (after discharge), had similar factors and items. In other words, both perceptions and expectations questionnaires had construct validity. In most validation studies of the SERVQUAL model, in various industries such as laboratory (27), information systems (28) and, transport companies (29), the researchers have only assessed the construct validity of perception part of SERVQUAL questionnaires; while, customer expectation of received service was assessed separately $(6,7)$. In this study the goodness of fit indexes were acceptable. Therefore, our instrument was valid to measure the gap of medical tourism service quality in hospital. One of the best indices to assess goodness of fit is the relative chi-square. Many scholars believe that the relative chi-square should be less than 3. In this study, a relative chi-square for expectation and perception questionnaire were 1.25 and 1.28 , respectively. The quantity of relative chi-square in this study was suitable. Root mean square error of approximation (RMSEA) was made based on model errors. The RMSEA ranges from 0 to 1 , with smaller values indicating a better model fit. A value of 0.06 or less is indicative of acceptable model fit. The quantity of RMSEA for expectation and perception questionnaire were 0.029 and 0.032 , respectively. The goodness of fit index (GFI) is a measure of fit between the hypothesized model and the observed covariance matrix. The GFI range between 0 and 1 , with a value of over 0.9 generally indicating an acceptable model fit. In this study, GFI for expectation and perception questionnaire were 0.89 and 0.88 respectively. This value indicated a suitable quantity of GFI. Finally, the comparative fit index (CFI) analyzes the model fit by examining the discrepancy between the data and the hypothesized model, while adjusting for the issues of sample size inherent in the chi-squared test of model fit, and the normed fit index. CFI values range from 0 to 1 , with larger values indicating a better fit; a CFI value of 0.90 or larger is generally considered to indicate acceptable model fit. In this study, CFI for both expectation and perception questionnaire had a very good value (30). In the current study, Cronbach Alpha was acceptable and questionnaire was reliable. In Parasuraman's studies in the insurance industry, banks and phone repair companies, the SERVQUAL questionnaire reliability was approved (13). The mentioned results show that the MTSQ questionnaire is a valid and reliable tool to measure the service quality of medical tourism. The questionnaire can be used to assess the service quality of medical tourism in Iranian hospitals.

\section{Conclusions}

The findings indicated that the medical tourism SERVQUAL questionnaire with 8 dimensions and 31 items is a valid and reliable tool to measure the service quality of medical tourism in Iran. This is the first tool that has been developed based on a SERVQUAL model to assess the service quality of medical tourism in Iran. Also, the results 
of the study can be used for health policy makers and hospital managers to determine the strengths and weaknesses of medical centers and medical tourism industry.

\section{Acknowledgments:}

This study is part of M.Sc. thesis for Mohammad Qolipour. This work was financially supported by grant: U-94078 from the Vice-Chancellor for Research Affairs of Ahvaz Jundishapur University of Medical Sciences. The authors would like to thank all participants in this research, particularly the key informants and families who participated in the study.

\section{Conflict of Interest:}

There is no conflict of interest to be declared.

\section{Authors' contributions:}

All authors contributed to this project and article equally. All authors read and approved the final manuscript.

\section{References:}

1) Turner L. 'First world health care at third world prices': globalization, bioethics and medical tourism. BioSocieties. 2007;2(3):303-25. doi: 10.1017/S1745855207005765.

2) Burns LR. Medical tourism opportunities and challenges: Illustration from US-India trade. International Journal of Healthcare Management. 2015;8(1):15-26. doi: 10.1179/2047971914Y.0000000091.

3) Kazemi Z. Study of effective factors for attracting medical tourist in Iran. Netherlands: Lulea University of Technology; 2007.

4) ZiaSheikholeslami N, Rezaeian M, Bahsoun M, Taghavipoor M. Medical tourism: The view of Rafsanjan Medical University staff. Iranian Journal of Epidemiology. 2010;5(4):31-6.

5) Johnson TJ, Garman AN. Impact of medical travel on imports and exports of medical services. Health Policy. 2010;98(2-3):171-7. doi: 10.1016/j.healthpol.2010.06.006.

6) Delgoshaei B, Ravaghi H, Abolhassani N. Importance-performance analysis of medical tourism in iran from medical tourists and medical services provider's perspective: 2011. Middle East Journal of Scientific Research. 2012;12(11):1541-7

7) Sarwar A. Medical Tourism in Malaysia: Prospect and Challenges. Iran J Public Health. 2013;42(8):795805. Epub 2013/08/01. PMID: 26056632; PMCID: PMCPMC4441909.

8) O'Connor SJ, Trinh HQ, Shewchuk RM. Perceptual Gaps in Understanding Patient Expectations for Health Care Service Quality. Health Care Manage Rev. 2000;25(2):7-23. PMid: 10808414

9) Abuosi AA, Atinga RA. Service quality in healthcare institutions: establishing the gaps for policy action. Int J Health Care Qual Assur. 2013;26(5):481-92. doi: 10.1108/IJHCQA-12-2011-0077.

10) Athiyainan A, O’Donnell B. Exploring graduates' perceptions of the quality of higher education. Journal of Institutional Research in Australasia. 1994;3(1):1-7.

11) Zarei A, Arab M, Froushani AR, Rashidian A, Tabatabaei SMG. Service quality of private hospitals: The Iranian Patients' perspective. BMC Health Serv Res. 2012;12(1):31. doi: 10.1186/1472-6963-12-31. PMCID: PMCPMC3306759.

12) Brown A, Eatock J, Dixon D, Meenan BJ, Anderson J. Quality and continuous improvement in medical device manufacturing. The TQM Journal. 2008;20(6):541-55. doi: 10.1108/17542730810909329.

13) Parasuraman A, Zeithaml V. SERVQUAL: A multiple-item scale for measuring customer perceptions of service quality. Journal of Retailing. 2000;64(1):12-40.

14) Cheng Lim P, Tang NK. A study of patients' expectations and satisfaction in Singapore hospitals. Int J Health Care Qual Assur. 2000;13(7):290-9. PMCID: PMC11484647. DOI: 10.1108/09526860010378735

15) Tucker JL, Adams SR. Incorporating patients' assessments of satisfaction and quality: an integrative model of patients' evaluations of their care. Managing Service Quality: An International Journal. 2001;11(4):27287. doi: 10.1108/EUM0000000005611.

16) Jabnoun N, Chaker M. Comparing the quality of private and public hospitals. Managing Service Quality: An International Journal. 2003;13(4):290-9. doi: 10.1108/09604520310484707.

17) Sadiq Sohail M. Service quality in hospitals: more favourable than you might think. Managing Service Quality: An International Journal. 2003;13(3):197-206. doi: 10.1108/09604520310476463.

18) Boshoff C, Gray B. The relationships between service quality, customer satisfaction and buying intentions in the private hospital industry. South African Journal of Business Management. 2004;35(4). 
19) Lawshe CH. A quantitative approach to content validity1. Personnel psychology. 1975;28(4):563-75. doi: 10.1111/j.1744-6570.1975.tb01393.x.

20) Ma J, Harvey ME, Hu MY. Assessing the multidimensional and hierarchical structure of SERVQUAL. Psychol Rep. 2007;101(2):378-91. doi: 10.2466/pr0.101.2.378-391.

21) Polit DF, Beck CT, Owen SV. Is the CVI an acceptable indicator of content validity? Appraisal and recommendations. Res Nurs Health. 2007;30(4):459-67. doi: 10.1002/nur.20199.

22) Wynd CA, Schmidt B, Schaefer MA. Two quantitative approaches for estimating content validity. West J Nurs Res. 2003;25(5):508-18. PMid: 12955968, PMC12955968.

23) Prakash S, Pallepati A. Cross-cultural content validation of a modified service quality questionnaire in Kannada. J Indian Assoc Public Health Dent 2016;14(2):171. doi: 10.4103/2319-5932.183811.

24) Soita PW. Measuring perceived service quality using SERVQUAL: A case study of the Uganda health and fitness sector. International Journal of Business and Social Science. 2012;3(5).

25) Mahalakshmi V, Saravanaraj M, Umarani T. Customers' perception about value added services rendered by banks. African Journal of Business Management. 2013;7(29):2845. doi: 10.5897/AJBM2013.7084.

26) Osborne JW, Costello AB. Best practices in exploratory factor analysis: Four recommendations for getting the most from your analysis. Pan-Pacific Management Review. 2009;12(2):131-46.

27) Cook C, Thompson B. Reliability and validity of SERVQUAL scores used to evaluate perceptions of library service quality. The Journal of Academic Librarianship. 2000;26(4):248-58. DOI: 10.1016/S00991333(00)00114-2

28) Jiang JJ, Klein G, Carr CL. Measuring information system service quality: SERVQUAL from the other side. MIS quarterly. 2002:145-66. doi: 10.2307/4132324

29) Bigne J, Martınez C, Miquel M, Andreu L. SERVQUAL reliability and validity in travel agencies. Annals of Tourism Research. 2003;30(1):258-62. doi: 10.1016/S0160-7383(01)00090-1.

30) Schreiber JB, Nora A, Stage FK, Barlow EA, King J. Reporting structural equation modeling and confirmatory factor analysis results: A review. The Journal of educational research. 2006;99(6):323-38. doi: 10.3200/JOER.99.6.323-338. 